HOW POTENT IS FISCAL POLICY IN AUSTRALIA?

\author{
Anthony J. Makin* \\ Griffith Business School \\ Griffith University \\ Gold Coast 4222 \\ Australia \\ t.makin@griffith.edu.au \\ Paresh Kumar Narayan \\ Faculty of Business and Law \\ Deakin University \\ Burwood 3125 \\ Australia \\ paresh.narayan@deakin.edu.au
}

*corresponding author

Paper forthcoming in Economic Papers 2011, 30(2). 


\title{
HOW POTENT IS FISCAL POLICY IN AUSTRALIA?
}

\begin{abstract}
This paper examines the efficacy of fiscal policy in Australia, focusing on the relationship between changes in the economy's consolidated fiscal imbalance and private sector saving over recent decades. We first examine the macroeconomic significance of the offset co-efficient between public saving and private saving, whose size effectively determines the effectiveness of fiscal activism. The approach innovatively suggests that these estimates simultaneously reflect Ricardian and other non-Keynesian explanations of private consumption, such as the life cycle and permanent income theories. Econometric estimation of the offset coefficient for Australia over the period 1980 to 2008 yields values of between 0.75 to near unity, which imply a small or near-zero fiscal multiplier, and that running budget surpluses to lift national saving is ineffective.
\end{abstract}

Keywords: fiscal policy, public saving, private saving, offset co-efficient, Australia JEL Codes: E6, H6

\section{Contents}

Introduction

Links Between Public and Private Saving

Previous Empirical Studies

Estimating the Public-Private Saving Offset Co-efficient

Concluding Comments 


\section{HOW POTENT IS FISCAL POLICY IN AUSTRALIA?}

Fiscal policy has been deliberately used by Australian governments over recent decades to influence macroeconomic activity in two distinct, yet seemingly contradictory, ways. The first has been to run budget deficits at times of recession to raise national income by boosting aggregate consumption spending; the second, to run budget surpluses in the upswing of the cycle to bolster national income by lifting national saving.

For instance, in the early 1980s, early 1990s and late 2000's federal governments deliberately enlarged budget deficits and lowered public saving through discretionary fiscal measures to stabilize national income during major economic downturns at those times (Australian Treasury 1992-93, 2009-10). Whereas at other times over the past three decades, budget surpluses were intended to raise national saving to bolster long run economic growth and lessen reliance on foreign saving to fund the economy's total investment needs (Australian Treasury 1996-7, 2007-8).

Using fiscal policy as a stabilization instrument during recessions presumes it effectively alters aggregate demand. However, this has been questioned on numerous theoretical and practical grounds. See, for instance, Fama (2009) Barro (2009) and Taylor (2009). A key argument against using fiscal stimulus is that the size of any fiscal multiplier will be small if the private sector reacts by altering its saving behaviour. 
Or, if the private sector reduces its saving during normal growth periods when public sector saving is rising, this renders a fiscal strategy aimed at lifting national saving ineffective as well. In both instances, the potency of fiscal policy can be gauged by the extent to which private saving offsets public saving.

In this paper we explain how and why this offset may occur with reference to numerous theoretical approaches, but ultimately its significance needs to be resolved empirically. Chart 1 depicts the two key data series central to our analysis, Australian public saving and private saving. It is apparent that there has been a significant offset of public and private saving over recent decades, the extent of which will be established econometrically.

\section{INSERT FIGURE 1}

The next section establishes basic underpinnings for interpreting the inter-relationship between private and public saving, highlighting the implications of the saving offset for short run stabilization policy and for using budget surpluses to lift national saving. Employing the latest time series methods it then econometrically estimates the size of the offset co-efficient using annual national accounts saving data for Australia and for the period 1980-2008. In preview it surprisingly suggests that the offset is almost complete in Australia's case. The conclusion draws implications for Keynesian-oriented fiscal theory and policy. 


\section{Links Between Public and Private Saving}

A standard Keynesian consumption function, the sine qua non of activist fiscal policies, illustrates how private and public saving are linked. Consider the usual specification in the form

$$
\mathrm{C}=\overline{\mathrm{C}}+\mathrm{cY^{ \textrm {d } }}
$$

where $\mathrm{C}$ is private consumption, $\overline{\mathrm{C}}$ is autonomous consumption, $\mathrm{c}$ is the propensity to consume, and $\mathrm{Y}^{\mathrm{d}}$ is disposable income, defined as

$$
\mathrm{Y}^{\mathrm{d}}=\mathrm{Y}-\mathrm{T}+\mathrm{T}^{\mathrm{r}}
$$

where $\mathrm{Y}$ is national income, $\mathrm{T}$ is taxes and $\mathrm{T}^{\mathrm{r}}$ is income transfers. The propensity to save, $\mathrm{s}$, is $1-\mathrm{c}$.

Private saving, $\mathrm{S}^{\mathrm{p}}$, the residual between disposable income and private consumption, is

$$
\begin{aligned}
& \mathrm{S}^{\mathrm{p}}=\left[\mathrm{Y}-\mathrm{T}+\mathrm{T}^{\mathrm{r}}\right]-\left[\overline{\mathrm{C}}+\mathrm{c}\left(\mathrm{Y}-\mathrm{T}+\mathrm{T}^{\mathrm{r}}\right)\right] \\
& \frac{\mathrm{dS}^{\mathrm{p}}}{\mathrm{dY}}=1-\mathrm{c}=\mathrm{s}, \quad \frac{\mathrm{dS^{ \textrm {p } }}}{\mathrm{dT}}=-\mathrm{s}, \quad \frac{\mathrm{dS}^{\mathrm{p}}}{\mathrm{dT}^{\mathrm{r}}}=\mathrm{s}
\end{aligned}
$$

Public saving, $\mathrm{S}^{\mathrm{g}}$, is simply the difference between government tax revenue, net of transfers, and government consumption spending, G, such that

$$
\begin{aligned}
& \mathrm{S}^{\mathrm{g}}=\left(\mathrm{T}-\mathrm{T}^{\mathrm{r}}\right)-\mathrm{G} \\
& \frac{\mathrm{dS^{ \textrm {g } }}}{\mathrm{dT}}=1, \quad \frac{\mathrm{dS^{ \textrm {g } }}}{\mathrm{dT}^{\mathrm{r}}}=-1, \quad \frac{\mathrm{dS^{ \textrm {g } }}}{\mathrm{dG}}=-1
\end{aligned}
$$

Macroeconomics textbooks presume the propensity to consume is usually around 0.6 or greater, or the propensity to save around 0.4 or less (Littleboy and Taylor 2009). The limit case of ( $c=1, s=0)$ implies that private saving does not offset public saving rises 
(falls) at all, whereas the opposite limit case of ( $c=0, s=1)$ implies private saving fully offsets public saving rises (falls), leaving total national saving unaffected. The former implies discretionary fiscal policy very effectively raises private consumption (saving) when expansionary (contractionary), whereas the latter implies fiscal policy is ineffective.

In other words, according to standard Keynesian theory, activist fiscal policy aimed at stimulating private consumption via tax cuts and transfers will cause public saving to fall, but private saving will rise only minimally because the propensity to consume is assumed to be high. This implies that the fiscal multiplier would be high in the first round, having a unity value if all of the tax cuts or transfers were immediately consumed. Moreover, if the government spends directly on consumption, there should be no offsetting reduction in private consumption in response. However, if on the contrary households treated tax cuts or transfer payments as temporary and, at the other extreme, fully saved them, the fall in public saving would be completely offset by an equivalent rise in private saving, implying the fiscal multiplier was zero.

The Keynesian consumption function also justifies using fiscal policy to raise public saving, and hence national saving. For instance, higher tax revenue when the economy and employment is growing at, or above, its trend rate of growth enlarges budget surpluses. As public saving rises, according to equation (4), private saving will fall minimally if the propensity to save is small, but yield an overall rise in national saving of (1-s ) dollar for each dollar of budget surplus arising from additional tax revenue. Like 
deploying budgetary policy for countercyclical purposes, this fiscal strategy becomes more effective, the higher the propensity to consume and lower the propensity to save.

Private saving could increase in response to budget deficits and reduced public saving for a number of non-Keynesian theory-based reasons. For instance, the life cycle (Modigliani 1986) and permanent income (Friedman 1957) theories of consumption imply that household consumption will not rise proportionately with a temporary income increase, as presumed in the simple Keynesian consumption function. For instance, if household consumption remained at its permanent level, the bulk of any temporary income increase from the budget would be saved. Taylor (2009) provides recent evidence of this for the United States.

The Ricardian equivalence proposition which generated a large earlier literature that flourished mostly in the 1980s (see Barro 1989, Bernheim 1987, Seater 1993, Ricciuti 2003) suggests when faced with higher budget deficits, households, wary of future taxes required to pay off new public debt, will save rather than spend. If a dollar of new public debt negates a dollar of consumer spending in this way, tax cuts and welfare payments prove ineffective as a stimulus measure, because they fail to induce additional private consumption.

In short, in response to changes in public saving the private sector may treat extra budget sourced income either as purely transitory rather than permanent, or there may be Ricardian behaviour. However, these possible causes of the saving offset are not 
mutually exclusive and private sector behaviour could reflect a combination of these and other factors.

\section{Previous Empirical Studies}

Empirical studies of the offset between public saving and private saving have mainly focused on this measure as a manifestation of the Ricardian equivalence proposition with many earlier studies providing evidence of a significant partial offset between public and private saving. Most of these studies have concluded that at least half of the change in fiscal balances in advanced economies was offset by an opposite change in private saving. (Bernheim (1987), Masson, Bayoumi and Hossein (1998), and Hemming, Kell and Mahfouz (2002)).

Later estimates by Edwards (1996) for developing countries found an offset coefficient of the same order, and more recent work by the IMF (2008) suggests the fall in private saving due to improvement in the fiscal balances of advanced economies during the 1990s was somewhat larger. In the most comprehensive study to date based on World Bank data, Loayaza, Schmidt-Hebbel and Serven (2000) found that for 150 countries the offset was close to 0.7 over the period 1965 to 1994 . In contrast, a study of OECD economies for the period 1970-2004 by Holmes (2006) concluded there was a much higher degree of substitutability between private and public saving.

The empirical evidence on the Keynesian transmission mechanism and fiscal multipliers is more mixed than that on Ricardian equivalance, with estimates of the effects of fiscal 
policy on key macroeconomic variables, including consumption and saving, differing both in magnitude and sign (IMF 2008). While there are studies that yield positive fiscal multipliers in support of the Keynesian paradigm, others suggest the opposite. For instance, Blanchard and Perotti (2002) provide empirical evidence in support, whereas Alesina, Perotti and Tavares (1998) and Auerbach (2002) do not. Meanwhile, numerous other studies (see for instance Campbell and Mankiw (1989) and Taylor (2009)) have separately examined private saving behaviour from Friedman's permanent income perspective of consumption. The results of these studies imply the Keynesian consumption function underlying fiscal multiplier analysis is not robust.

In short, earlier studies have examined the nexus between public and private saving using both Keynesian and non-Keynesian rationales. An innovation of this paper is that it approaches this issue in an encompassing way for Australia using more comprehensive measures of public and private saving than used in previous studies. Evidence of a low public-private saving offset coefficient would support fiscal activism and the Keynesian perspective, whereas a high offset co-efficient would affirm that non-Keynesian effects, jointly tested, predominate.

\section{Estimating the Public-Private Saving Offset Co-efficient}

The estimable relationship is specified as

$$
S_{t}^{p}=\alpha+\beta S_{t}^{g}+\mu_{t}
$$


where $\mathrm{S}^{\mathrm{p}}$ is private sector saving as a proportion of GDP $\mathrm{S}^{\mathrm{g}}$ is public sector saving as a proportion of GDP, and $\beta$ is the measure of the public-private offset, having a value between zero (no offset) and negative unity (full offset).

The data we use is annual public and private saving data from the Australian Bureau of Statistics, System of National Accounts, Catalogue No. 5204.0, Table 14, for the years 1980 to 2008, expressed as a share of GDP. In contrast to earlier international studies that use national budget imbalances as proxies for public saving, this study uses a more comprehensive measure of public saving. This broader measure represents the consolidated budgetary position of all tiers of government in Australia, and reflects the difference between net government revenue and public consumption spending. Hence, we do not account for the effects of public investment which was remarkably stable over the data period, averaging only ten per cent of total public spending. Private saving is the combined saving of the households, firms and financial institutions.

Our approach to modeling proceeds as follows. Two possibilities exist. First, it is likely that private and public savings are cointegrated. The graph (see Figure 1) suggests a strong convergence of public and private savings, implying the possibility of a cointegration relationship. However, this needs to be empirically ascertained. This is a crucial step because if in case the two variables are indeed cointegrated then this will pave the way for estimating beta in both the short-run and long-run. Second, the proposed estimable relationship depicted in (6) may merely be a short-run relationship, which is what we hypothesize given our theoretical discussion earlier. 
We begin the empirical analysis in three stages. In the first stage, we will test the integrational properties of the data series. This outcome will determine whether or not we can test for any possible long-run relationship between public and private savings. In other words, non-stationarity is a pre-requisite for testing for cointegration. To achieve this, we apply the Ng and Perron (2001) test. They propose four test statistics that are based upon the generalised least squares (GLS) de-trended data series. The results reported in Tables 1 and 2 suggest that both private and government savings are integrated of order one.

\section{INSERT TABLES 1-2}

In the second stage, we test for cointegration between private saving and public saving. The test for cointegration between private saving and public saving, within an Engle Granger (1987) framework, amounts to extracting the residuals from equation (5)—our proposed model — and subjecting it to a test for unit roots. This can be expressed as follows:

$$
\Delta \hat{\mu}_{\mathrm{t}}=\rho_{1} \hat{\mu}_{\mathrm{t}-1}+\sum_{\mathrm{i}=1}^{\mathrm{p}} \gamma_{\mathrm{i}} \Delta \hat{\mu}_{\mathrm{t}-\mathrm{i}}+\varepsilon_{\mathrm{t}}
$$

A null of a unit root is then tested, such that $\rho_{1}=1$. We subject the residuals to a test of unit roots by using the augmented Dickey and Fuller (1979) test. In our test model, we only have an intercept. The optimal lag length is determined by using the Schwarz information criteria. The optimal lag length turns out to be 1 . The test statistic turns out to be -2.9 (with a probability value of 0.058 ). This implies that we are able to reject the null hypothesis of a unit root at the 6 per cent level. Hence, there is evidence of a cointegration relationship between private saving and government saving for Australia. 
The residual based test is misspecified if adjustment is asymmetric. Hence, we also model the relationship in an asymmetric manner by letting the deviations from the longrun equilibrium behave as a threshold autoregressive (TAR) process. This can be expressed as follows

$$
\Delta \hat{\mu}_{\mathrm{t}}=\mathrm{I}_{1} \rho_{1} \hat{\mu}_{\mathrm{t}-1}+\left(1-\mathrm{I}_{\mathrm{t}}\right) \rho_{2} \hat{\mu}_{\mathrm{t}-1}+\varepsilon_{\mathrm{t}}
$$

where $I_{t}$ is a Heaviside indicator function such that

$$
I_{t}=\left\{\begin{array}{lll}
1 & \text { if } & \mu_{t-1} \geq \tau \\
0 & \text { if } & \mu_{t-1}<\tau
\end{array}\right.
$$

where $\tau$ is the value of the threshold and $\left\{\varepsilon_{t}\right\}$ is a sequence of zero mean, constant variable iid random variables, such that $\varepsilon_{\mathrm{t}}$ is independent of $\mu_{\mathrm{j}}, \mathrm{j}<\mathrm{t}$. As shown by Petrucelli and Woolford (1984), the necessary and sufficient conditions for the stationarity of $\left\{\mu_{\mathrm{t}}\right\}$ is $\rho_{1}<0, \rho_{2}<0$ and $\left(1+\rho_{1}\right)\left(1+\rho_{2}\right)<1$ for any value of $\tau$. In (7) is a case where the Heaviside indicator depends on the level of $\mu_{t-1}$.

Under the null hypothesis of no convergence, the F-statistic, denoted $\Phi^{\mathrm{C}}$ by Enders and Siklos (2001), has a non-standard distribution. The speeds of adjustment are represented by $\rho_{1}$ and $\rho_{2}$. If the null hypothesis is rejected it is possible to test for symmetric adjustment, which can be achieved by setting $\rho_{1}=\rho_{2}$. 
Enders and Granger (1998) and Caner and Hansen (1998) suggested an alternative such that the threshold depends on the previous periods change in $\mu_{t-1}$. This can be achieved by setting the Heaviside indicator as follows:

$\mathrm{M}_{\mathrm{t}}=\left\{\begin{array}{lll}1 & \text { if } & \Delta \mu_{\mathrm{t}-1} \geq \tau \\ 0 & \text { if } & \Delta \mu_{\mathrm{t}-1}<\tau\end{array}\right.$

Models to test for the stationarity of the residuals using Equations (6) and (8) are regarded by Enders and Siklos (2001) as momentum-threshold autoregressive (M-TAR) models simply because the residual exhibits more momentum in one direction than the other. Appropriate critical values for the TAR and M-TAR models are extracted from Enders and Siklos (2001).

The results are reported in Table 3. We begin the discussion of the results with the TAR model. We find that the t-Max statistics turns out to be -2.93 . Compared with the critical value at the 10 per cent level, extracted from Enders and Siklos (2001: 170), of -1.91, the calculated t-Max statistic is smaller than the critical value. The $\Phi^{\mathrm{C}}$ statistic of 4.5 is greater than the 10 per cent level critical value of 4.32 . Hence, at the 10 per cent level, we are able to reject the null hypothesis of no cointegration, implying that the TAR model finds evidence of cointegration between private saving and public saving.

Next we consider the results on cointegration from the M-TAR model. The t-Max statistic is -1.96 which is smaller than the 10 per cent level critical value of -1.92 . This implies that, as with the results from the TAR model, we are able to reject the null of no cointegration. Moreover, the $\Phi^{\mathrm{C}}$ statistic of 10.3 is greater than the 10 per cent level 
critical value of 4.32. Taken together, then, we are able to reject the null hypothesis of no cointegration at conventional levels of significance and conclude that private savings and public savings are cointegrated for Australia.

\section{INSERT TABLE 3}

In the third step, we estimate the impact of government saving on private saving. Having found evidence of cointegration and having established that private saving and public saving are I(1), equation (6) can be estimated in its proposed form.

We used the OLS estimator to estimate the coefficient on $\beta$ and find based on three different estimators, namely the OLS, the Dynamic OLS proposed by Stock and Watson (1993), and the FMOLS proposed by Phillips and Hansen (1990) that the coefficient of beta ranges between -0.74 to -0.99 . All three estimators reveal that coefficient on government savings is statistically significant at the 1 per cent level. The results are presented below.

Based on OLS:

$$
S_{t}^{p}=\underset{(15.651)}{-5.2266^{* * * *}}-\underset{(-5.314)}{0.7479^{* * *}} S_{t}^{g}+\mu_{t}
$$

\section{Based on DOLS:}

$$
S_{t}^{p}=\underset{(9.172)}{4.9694^{* * *}}-\underset{(-3.647)}{0.9973^{* * *}} S_{t}^{g}+\mu_{t}
$$

Based on the FMOLS:

$$
S_{t}^{p}=\underset{(8.979)}{5.1183^{* * *}}-\underset{(-4.109)}{0.8697^{* * *}} S_{t}^{g}+\mu_{t}
$$

\section{INSERT FIGURE 2}


In Figure 2, we also plot the rolling least squares coefficient over a 10-year window period. The trend clearly shows the negative coefficient on public savings.

\section{Concluding Comments}

In recent decades governments around the world have frequently implemented activist fiscal policies in response to recessions that have lowered public saving (IMF 2009). The express aim of discretionary policies that reduce public saving is to increase private consumption and aggregate demand on the presumption that households will spend, not save, most of the proceeds. Yet, what is central to any analysis of the efficacy of fiscal policy is how the private sector reacts to the larger budget deficits and rising public debt that stem from income tax cuts, temporary tax bonuses and transfers, and higher public consumption.

In Australia's case, it was also an explicit goal of a series of federal budgets throughout the 1990's and 2000's to increase national saving via budget surpluses in order to reduce the economy's dependence on foreign borrowing to fund its total investment requirement. Implicitly, this fiscal policy objective was founded on the Keynesian presumption that consumption essentially depends on current disposable income, and that private saving does not vary to offset changes in public sector saving.

However, this paper has shown that, in reality, private saving has offset changes in public saving, a phenomenon that can be explained with reference to compatible, non-Keynesian perspectives on private saving behaviour, including the life cycle and permanent income 
theories of consumption, as well as Ricardian equivalence. The innovative allencompassing approach of our approach does not necessarily imply support for any one of these perspectives, taken on its own. For instance, it neither supports near full Ricardian equivalence by itself, nor the life cycle or permanent income approaches to consumption. Disentangling which of these perspectives best explain the offset, or identifying their respective contributions, remains a challenge for future research.

In terms of macroeconomic policy, the results of this paper suggest that fiscal policy strategies adopted by various Australian governments of alternative political persuasion over recent decades, either to use budget deficits to counter economic downturns, or at other times build budget surpluses to lift national saving, have been almost entirely impotent in achieving their intended goals. Not only does this imply fiscal stimulus during recessions is ineffective, so too is running budget surpluses via higher income taxes to lift national saving in more buoyant times. 


\section{References}

Australian Bureau of Statistics, (2009) System of National Accounts Cat 5204.0 available at www.abs.gov.au

Australian Treasury, Annual Budget Papers, various available at www.treasury.gov.au

Alesina, A. Perotti, R. and Tavares, J. (1998) “The Political Economy of Fiscal Adjustments” Brookings Papers on Economic Activity, 1: 197-266.

Auerbach, A. (2002) 'Is There a Role for Discretionary Fiscal Policy?’ NBER Working Paper 9306, National Bureau of Economic Research, October.

Barro, R. (2009) "Demand Side Voodoo Economics," The Economists' Voice 6, 2, Article 5.

Barro, R. (1974) “Are Government Bonds Net Wealth?” Journal of Political Economy, 81, 1095-1117.

Bernheim, D. (1987) "Ricardian Equivalence: An Evaluation of Theory and Evidence” in S. Fischer (ed.) NBER Macroeconomics Annual 1987, Cambridge, MIT Press, Massachusetts.

Blanchard, O. and Perotti R. (2002) 'An Empirical Characterization of the Dynamic Effects of Changes in Government Deficit and Taxes on Output,' Quarterly Journal of Economics 117:4, 1329-1368.

Campbell, J. and Mankiw, G. (1989) “Consumption, Income and Interest Rates: Reinterpreting the Time Series Evidence” NBER Macroeconomics Annual 1989, NBER, New York. 
Caner, M. and Hansen, B. (1998), Threshold Autoregression with a Near Unit Root, Working Paper, University of Wisconsin.

Dickey, D. A. and Fuller , W. A. (1979) Distribution of the estimators for autoregressive time series with a unit root, Journal of the American Statistical Association, 74, pp. 427431.

Edwards, S. (1996) "Why are Latin America's savings rates so low? An international comparative analysis," Journal of Development Economics, 51(1), 5-44.

Enders, W. and Granger, C. W. J. (1998) Unit root tests and asymmetric adjustment with an example using the term structure of interest rates, Journal of Business and Economic Statistics, 16, pp. 304-311.

Enders, W. and Siklos, P.L. (2001) 'Cointegration and Threshold Adjustment”, Journal of Business and Economic Statistics, 19, 166-76.

Engel, R.F. and Granger, C. W. J., (1987) Cointegration and Error Correction Representation, Estimation and Testing. Econometrica, 55, 251-276.

Fama, E. (2009) “Bailouts and Stimulus Plans” Available at www.dimensional.com/famafrench/2009/01/bailouts-and-stimulus-plans.html

Friedman, M. (1957) A Theory of the Consumption Function, Princeton University Press, 
New Jersey.

Hemming, R, Kell, M and Mahfouz, S (2002) "The Effectiveness of Fiscal Policy in Stimulating Economic Activity" IMF Working Paper WP/02/208, International Monetary Fund.

Holmes, M. (2006) “To What Extent Are Public Savings Offset by Private Savings in the OECD?” Journal of Economics and Finance 30 (3), 285-296.

International Monetary Fund (2009) Global Economic Policies and Prospects, Group of Twenty Meeting, March, IMF, Washington DC.

International Monetary Fund (2008) World Economic Outlook, September, IMF, Washington DC.

Keynes, M. (1936) The General Theory of Employment, Interest and Money Macmilllan, Houndsmills, UK.

Littleboy, B. and Taylor, J. (2009) Macroeconomics $4^{\text {th }}$ ed, Wiley, Brisbane.

Loayza, N. Schmidt-Hebbel, K. and Serva, L. (2000) "What Drives Private Saving Across the World?” Review of Economics and Statistics 82, 165-181.

Masson, P. Bayoumi, T., Samiei, H. (1998) “International Evidence on the Determinants of Private Saving” World Bank Economic Review 12: 483 - 501.

Modigliani, F. (1986) “Life Cycle, Individual Thrift, and the Wealth of Nations” 
American Economic Review 76, June, 297-313.

Ng, S., and Perron, P., (2001) Lag length selection and the construction of unit root tests with good size and power, Econometrica, 69, 1519-1554.

Petrucelli, J. and Woolford, S. (1984), ‘A Threshold AR(1) Model’, Journal of Applied Probability, 21, 270-86.

Phillips, P.C.B. and Hansen, B.E. (1990) 'Statistical inference in instrumental variable regression with I(1) processes’. Review of Economic Studies, 57, 99-125.

Ricciutti, R "Assessing Ricardian Equivalence” Journal of Economic Surveys (17, 1, 2003).

Seater, J. 1993. “Ricardian Equivalence.” Journal of Economic Literature, 31(1): 14290.

Stock, J.K., and Watson, M. (1993) 'A simple estimator of cointegrating vectors in higher order integrated systems’. Econometrica 61, 783-820.

Taylor, J. (2009) “The Lack of an Empirical Rationale for a Revival of Discretionary Fiscal Policy” in S. Kirchner (ed) Fiscal Fallacies, Centre for Independent Studies, St Leonards. 
Table 1: Ng and Perron (2001) unit root test for government saving

\begin{tabular}{|l|c|c|c|c|}
\hline & MZa & MZt & MSB & MPT \\
\hline Test statistic & -3.6566 & -1.2888 & 0.3525 & 6.7145 \\
\hline CV-1\% & -13.800 & -2.580 & 0.1740 & 1.780 \\
\hline CV-5\% & -8.100 & -1.980 & 0.2330 & 3.170 \\
\hline CV $-10 \%$ & -5.700 & -1.620 & 0.2750 & 4.450 \\
\hline
\end{tabular}


Table 2: Ng and Perron (2001) unit root test for private saving

\begin{tabular}{|l|c|c|c|c|}
\hline & MZa & MZt & MSB & MPT \\
\hline Test statistic & -1.561 & -0.701 & 0.4489 & 12.417 \\
\hline CV-1\% & -13.800 & -2.580 & 0.1740 & 1.780 \\
\hline CV-5\% & -8.100 & -1.980 & 0.2330 & 3.170 \\
\hline CV-10\% & -5.700 & -1.620 & 0.2750 & 4.450 \\
\hline
\end{tabular}


Table 3: Threshold cointegration test

\begin{tabular}{lcc}
\hline & Threshold & Momentum \\
\hline$\rho_{1}$ & $-0.6221^{* * *}$ & $-1.9595^{* * *}$ \\
& $(-2.9270)$ & $(-3.4501)$ \\
$\rho_{2}$ & -0.1172 & $-1.5976 * * *$ \\
& $(-0.6684)$ & $(-4.4964)$ \\
$\gamma_{1}$ & 0.1845 & $0.6961^{* *}$ \\
& $(1.1090)$ & $(2.5279)$ \\
$\gamma_{2}$ & $-0.4021^{* *}$ & 0.1977 \\
$\Phi^{\mathrm{C}}$ & $(-2 / 3372)$ & $(0.9456)$ \\
& $4.4502^{* *}$ & $10.2517^{* * *}$ \\
$\rho_{1}=\rho_{2}$ & {$[0.0238]$} & {$[0.0008]$} \\
& $3.4651^{*}$ & 0.7514 \\
& {$[0.0761]$} & {$[0.3958]$} \\
\hline
\end{tabular}


Figure 1 - Private and Public Saving

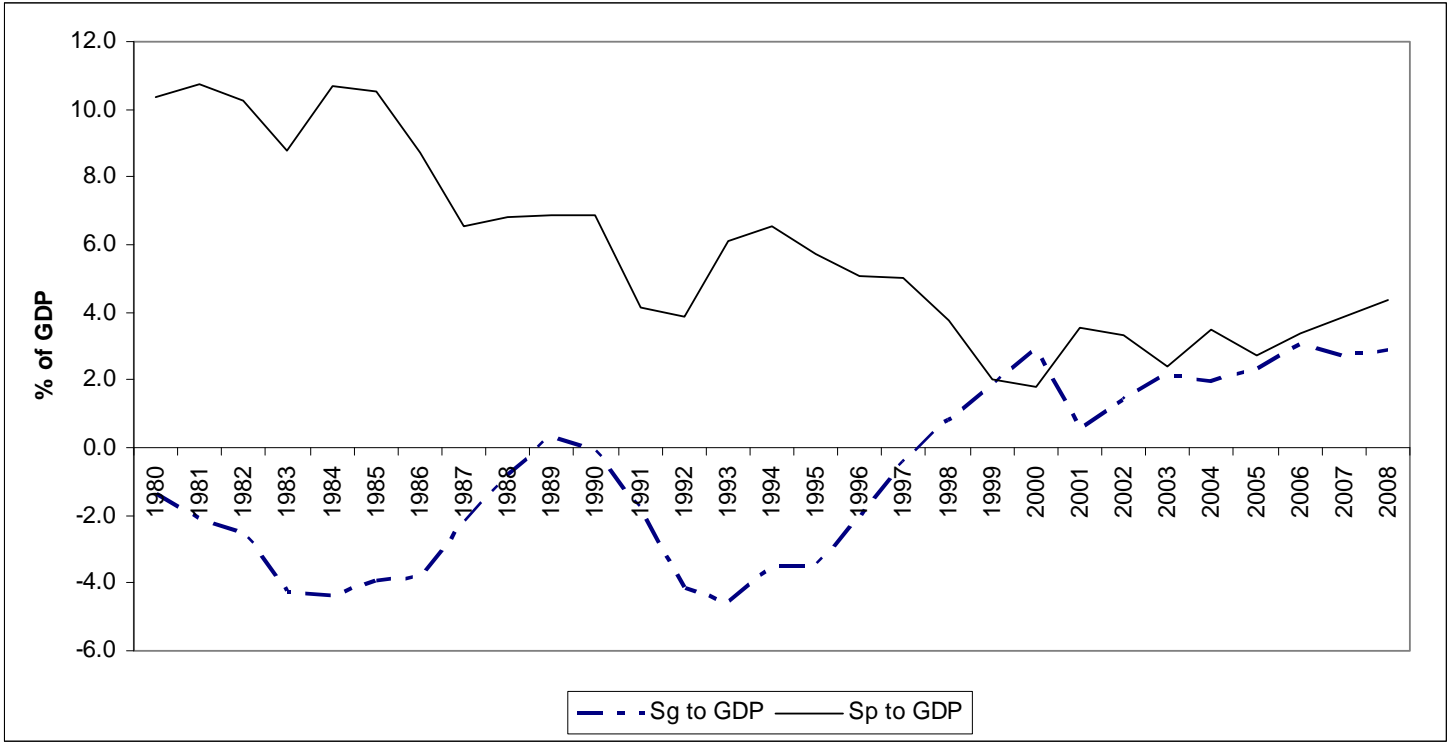

Source: Based on data from Australian Bureau of Statistics, System of National Accounts, Catalogue 5304.0, Table 14. 
Figure 2: Rolling least squares linear regression

$$
\text { Coefficient of SG and its two*S.E bands based on rolling OLS }
$$

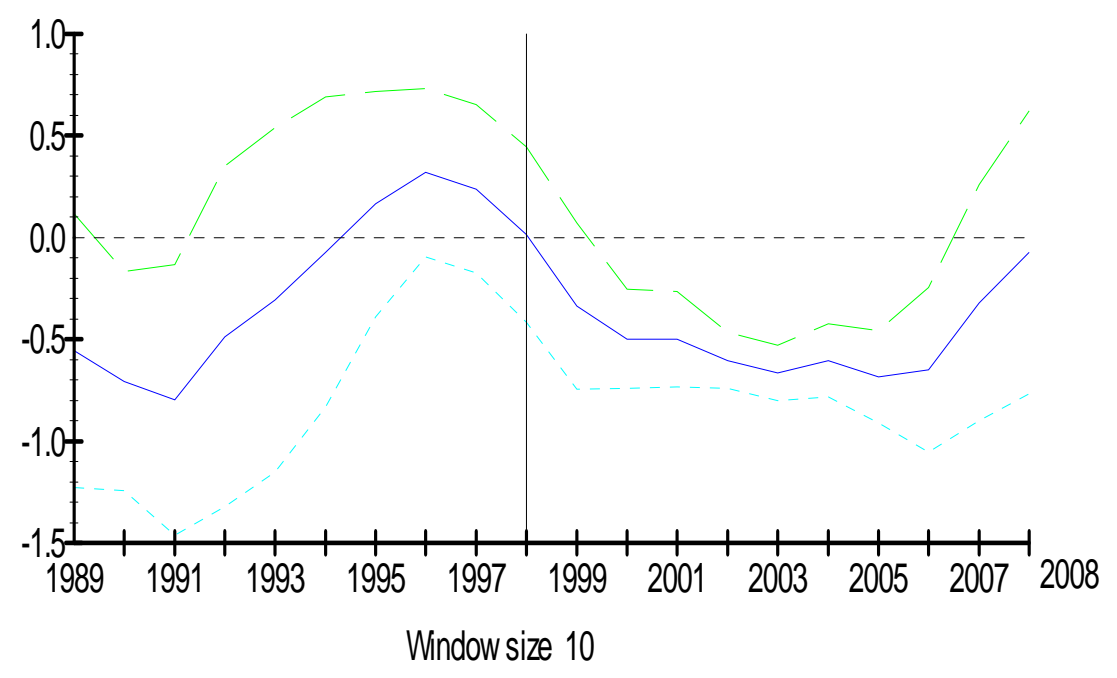

